\title{
パルス型プラズマスラスタの二段放電動作*1 Double Discharge Operation for a Pulsed Plasma Thruster
}

\author{
大 川 恭 志*2 橘 武 史*3 \\ Yasushi OKAwA and Takeshi TACHIBANA
}

Key Words : Propulsion, Electric Propulsion, Pulsed Plasma Thruster, Late-Time Vaporization

\begin{abstract}
Double discharge operation for a pulsed plasma thruster (PPT) was proposed and the preliminary experiments were conducted to improve the lower propellant utilization efficiency of PPTs that is attributable mainly to a late-time vaporization problem. In the double discharge operation, two successive discharges were produced with a microseconds-order interval to accelerate the late-time vaporization gas generated in a primary discharge by the electromagnetic interaction in a secondary one. Experimental results showed by adopting the double discharge operation the effective exhaust velocity was increased compared with the one in the ordinary PPT operation. This velocity increment indicated that the ratio of electromagnetically accelerated propellant gas to total propellant consumption was risen in the double discharge operation. Furthermore, when the time interval between the two discharges was shorter than the single discharge duration, it was observed that the impulse bit, specific impulse and thruster efficiency were higher than those in the ordinary operation.
\end{abstract}

\section{1. は じめに}

パルス型プラズマスラスタ (Pulsed Plasma Thruster , $\mathrm{PPT})$ は, 電気エネルギを運動エネルギに変換して推力を 得る電気推進機の一種であり, 小型, 軽量および簡便な機 構を特徵とする．近年，打上コスト削減やリスク低減等の 要求から, 重量 $50 \mathrm{~kg}$ 程度以下の小型人工衛星の需要が高 まっており, 上記の特徴を有する PPT はこれら小型衛星の 姿勢制御や軌道離脱用の推進機として注目を浴びてきてい る.特に, ポリテトラフルオロエチレン (PTFE) 等の高 分子化合物を推進剂とする固体推進斉型 $\mathrm{PPT}$ (固体 $\mathrm{PPT}$ ) は, 弚の簡便な機構による信頼性の高さから, 衛星搭載の 実績も多い1). しかしながら，短時間のアーク放電からの 入熱により固体推進剂を昇華させる機構を持つ固体 $\mathrm{PPT}$ には，推進剂消費量の制御が困難であるという本質的な問 題があり，これが他の電気推進機に比較して大幅に推進効 率が低い原因となっている. 本研究は，この推進剂消費の 問題に着目して固体 PPT の推進性能向上を目指すもので ある

通常の固体 PPT の動作では, 始めにイグナイタの小エ ネルギ放電によって電極間の絶縁破壊が生じ, 高電圧コン デンサに蓄えられた電気エネルギが解放されることで, パ ルス大電流アーク (ピーク電流〜 $10 \mathrm{kA}$ ) が電極間に形成 される．このアーク放電は, 発生直後の段階では推進剂表 面近傍に存在しており, アーク柱からの放射および高温粒

\footnotetext{
*1 (C) 2003 日本航空宇宙学会

平成 14 年 6 月 6 日原稿受理

$* 2$ 日本学術振興会

$* 3$ 九州工業大学工学部
}

子の流入が熱輸送の主な担い手となって，推進剂表層部の 蒸気化がなされると考えられている.この状態の後, 電流 ループによる自己誘起磁場とアーク電流とのローレンツ作 用により，アーク柱自体は下流方向に加速・排出され，推 力が発生する .このような機構により，固体 PPT におい ては推進剂供給用のタンクやバルブ, マニホールド等が必 要なく，この簡便性が固体 PPT の最大の特徵であると言 える .

しかしながら ,プラズマ加速が行われるアーク放電の持続

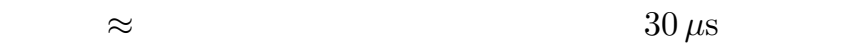
して, 推進剂表層部での熱輸送に要する時間 $(100 \mu \mathrm{s}$ オー ダー) が長いため, 推進斉の全蒸気化量のうちの多くの割 合が放電終了後に放出され ${ }^{2 \sim 4)}$, 有効な電離・加速がなされ ないと考えられている .これが Late-Time Vaporization (LTV) と呼ばれる現象であり，LTV ガスの排気速度は， ローレンツ加速によるプラズマ排気速度に比較して一桁以 上小さいため, LTV 現象は固体 PPT の低推進性能の最も 大きな要因の一つとなっている .

本稿では，このLTV ガスを効率的に電磁加速するための 手段として, 固体 PPT の二段放電動作 (Double Discharge Operation $)^{5)}$ を提案するとともに, 光の初期実験の結果に ついて報告する．

\section{PPT の二段放電動作}

本研究で提案する PPT の二段放電動作とは, 1 回の推 力発生動作の中で, $\mu \mathrm{s}$ オーダーの間隔で 2 回の連続した放 電を発生させるものであり，1 段目の放電 (Primary discharge，PD) により生じた LTV ガスが電極間に残留して いる間に 2 段目の放電 (Secondary discharge , SD) を発 


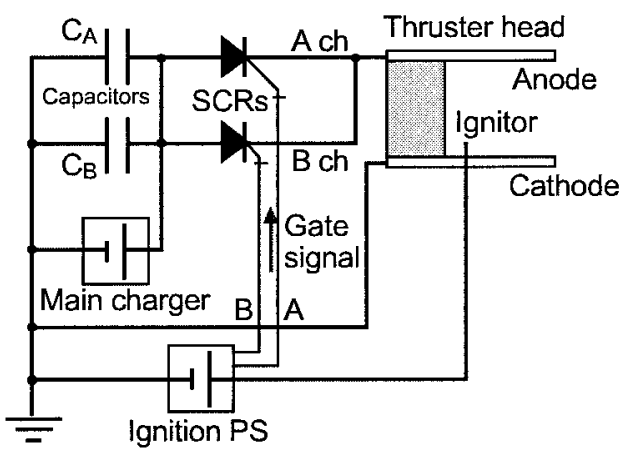

第 1 図 二段放電動作用 PPT 回路

生させ，PD の LTV ガスを有効に電離・加速することを 狙ったものである．本動作により，全推進斉消費量に対す る LTV ガス割合の低下，および有効排気速度の増大か期待 できるものと考えられる . 本実験では , $25 \mu \mathrm{s}$ の放電の後に $300 \mu \mathrm{s}$ 程度推進剂の蒸気化が持続したとする LTV 現象の 測定結果例2) を参考にして，PD と SD の時間間隔 (Delay time,$\tau)$ を決定した .

第 1 図に PPT の二段放電動作用回路を示す．短時間間 隔での連続放電は, PPT の陽極に接続された 2 系統のコ ンデンサおよび大容量サイリスタによって実現される . 同 図中，A-ch が PD 用，B-ch が SD 用のエネルギ導入回路 であり，イグナイタへの着火信号と同時に，任意の時間間 隔をおいて A-ch と B-ch に乥れゲート信号を送ること により， $\mu \mathrm{s}$ オーダーの間隔での連続した二段放電動作を可 能としている . ただし, 本回路を用いることにより，通常 の PPT の動作で生じる放電電流の反転成分は除去される ため，この反転電流により発生する推力分（回路の抵抗や インダクタンスに依存するが , 本実験の設定では全推力の $10 \%$ 程度) は, 二段放電動作においては回路損失になると 考えられる 。

また，今回の二段放電動作実験では，PD および SD の両 方でイグニション放電を発生させたが, 後述のように, SD におけるイグニション放電の要不要は, 設定した放電間隔 $\tau$ に依存するものであった .

\section{3. 実験装置および実験方法}

本研究で使用した実験装置の概略を第 2 図に示す. 真空 槽は直径 $0.3 \mathrm{~m} \times$ 長さ $0.6 \mathrm{~m}$ の円筒形であり, ターボ分子 ポンプおよび油回転ポンプによる 2 段の真空排気がなされ ている.PPT 動作中の真空度は 0.5 Pa 以下であった . また， コンデンサバンクを含めた電源系はすべて真空槽外に設置 されており，これらは電流導入端子により真空槽内の PPT ヘッドに接続されている .このため, PPT 主放電回路のイ ンダクタンスおよび抵抗は, 他機関での研究と比較して大 きな値となっている (単段放電動作の場合で, $L \approx 2.5 \mu \mathrm{H}$, $R \approx 250 \mathrm{~m} \Omega$ ).

主な測定項目は，インパルスビット (1 回の推力発生動 作による力積， $I_{\mathrm{b}}$ ) , マスショット (1 回の推力発生動作に より消費される推進斉重量， $\Delta m)$ ，および放電電流波形の

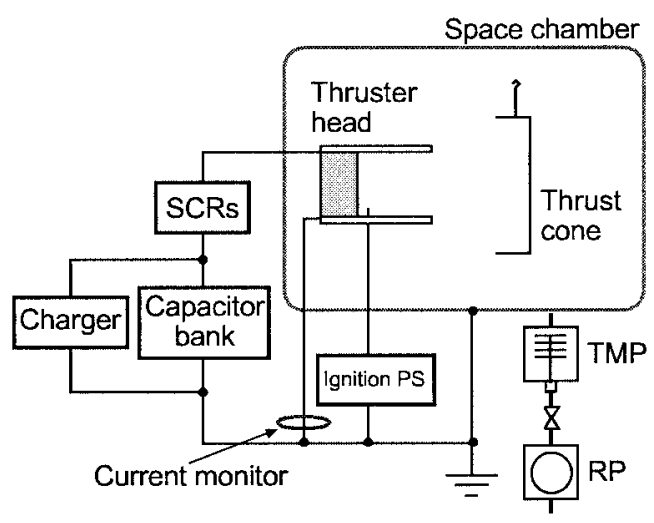

第 2 図実験装置概要

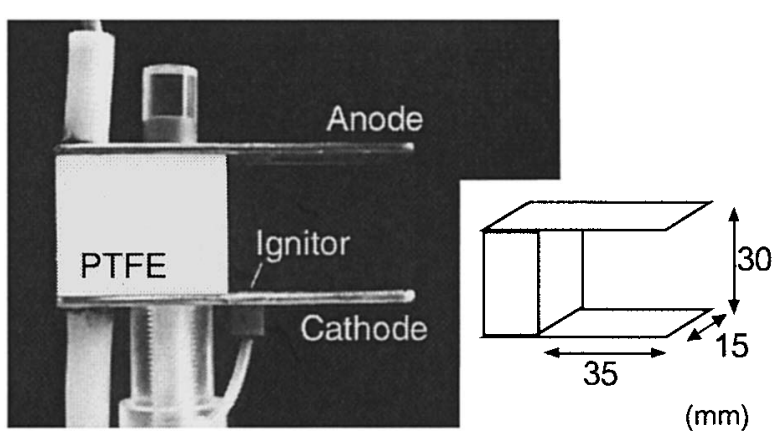

第3図 PPT ヘッド

3 項目とした .インパルスビットは, 文献 6) を参考に製作 した微小推力測定用の推力振り子により測定し, 各動作点 での 5 6 回の測定值の単純平均を兴の動作点での測定結 果とした . 各条件におけるインパルスビットの測定誤差は 最大約 $30 \%$ であり，標準偏差の最大は約 $4 \mu \mathrm{N} \cdot \mathrm{s}$ であった . また，マスショットは約 500 回の推力発生動作の前後にお ける推進剂の重量変化から計算しており, この值について は，予備実験において 5000 回の運転を行った場合との誤 差が $10 \%$ 以内であることを確認している . 比推力および推 進効率は , このインパルスビットおよびマスショットの測 定結果から算出した . 上記の測定誤差範囲は, 第 4 章に後 述する二段放電動作による性能変化量と同等のものである が, 第 4 章の議論は複数の投入エネルギ条件およびコンデ ンサ容量比条件における実験結果に基づくものであり，十 分な再現性があるものと考えられる . 放電電流波形は市販 の電流プローブにより測定した .

第 3 図に本実験に用いた PPT ヘッドを示す．本スラス タは，推進剤にPTFE を用いた平行平板電極型 PPT であ り，電極材料にはモリブデンを使用している．電極幅 $d$ は 陽極，陰極とも $15 \mathrm{~mm}$, 電極間隔 $h$ は $30 \mathrm{~mm}$, イグナイ 夕位置は推進剤端面から $5 \mathrm{~mm}$ 下流とした。

実験の主な設定值を第 1 表に示す．本実験では，通常の PPT 回路を用いた単段放電動作 (Ordinary discharge operation)，および第 1 図の回路を用いた二段放電動作の両者 を，総投入エネルギを同等とした条件で比較した . 全ての設 定において総コンデンサ容量は約 $18.5 \mu \mathrm{F}$ であり, 放電電圧 


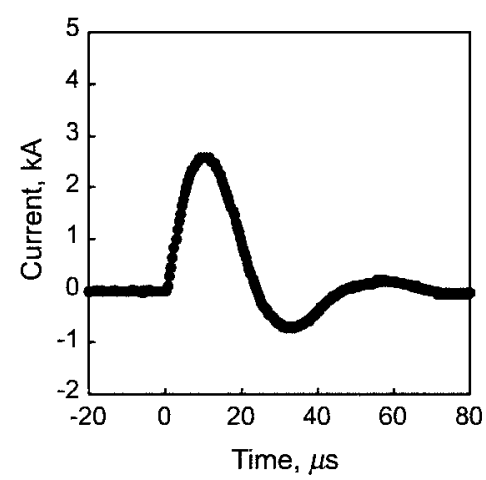

(a) Ordinary

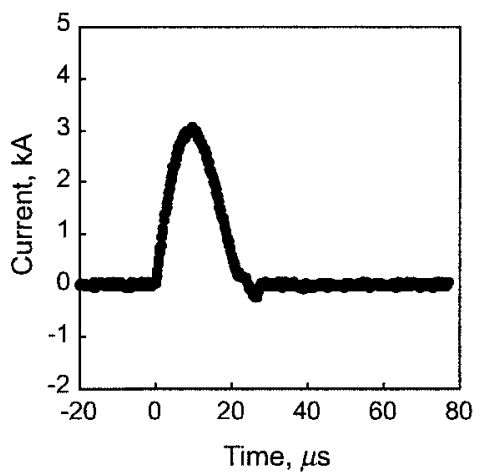

(b) Double $(\tau=0 \mu \mathrm{s})$

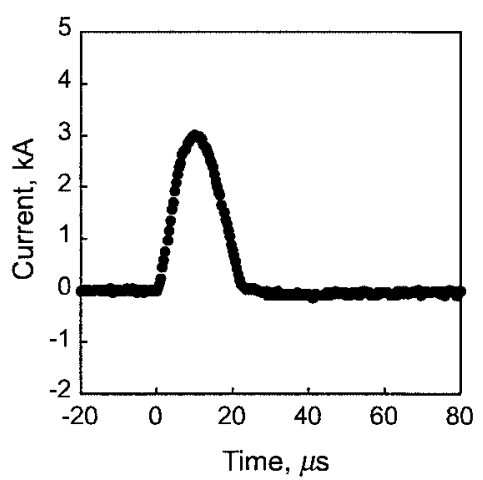

(c) Double $(\tau=5 \mu \mathrm{s})$

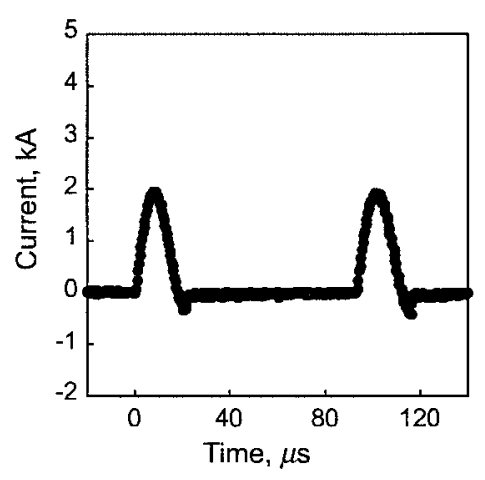

(d) Double $(\tau=100 \mu \mathrm{s})$

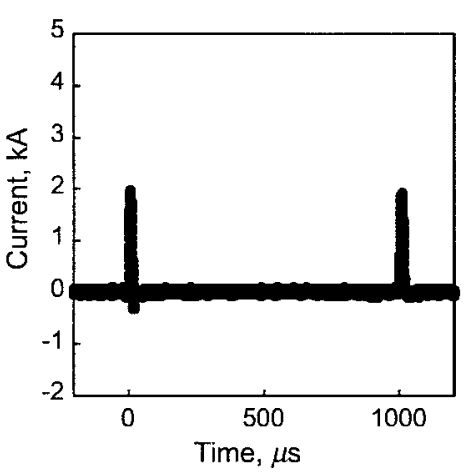

(e) Double $(\tau=1000 \mu \mathrm{s})$

第 4 図 単段放電動作および各二段放電動作の放電電流波形 $\left(E \approx 23 \mathrm{~J}, C_{\mathrm{A}} / C_{\mathrm{B}}=2 / 2\right.$ (for Double Discharge) $)$

第 1 表 設 定 値

\begin{tabular}{lcc}
\hline & Ordinary & Double discharge \\
\hline Propellant & PTFE & PTFE \\
Total capacitance $(\mu \mathrm{F})$ & 18.5 & 18.5 \\
Ignitor voltage $(\mathrm{kV})$ & 2.0 & 2.0 \\
Discharge voltage $(\mathrm{kV})$ & $1.0-2.2$ & $1.0-2.2$ \\
Capacitance ratio, $C_{\mathrm{A}} / C_{\mathrm{B}}$ & - & $4 / 0,3 / 1,2 / 2,1 / 3$ \\
Delay time, $t(\mu \mathrm{s})$ & - & $0,5,100,1000$ \\
\hline
\end{tabular}

を変化させることで総投入エネルギを決定している .二段放 電動作については, PD と SD との放電間隔 $\tau$ を主パラメー タとし，本実験系の放電回路特性（放電持続時間 $\approx 25 \mu \mathrm{s}$ ) および文献 2) を参考にして $\mathrm{PD}$ と SD の発生を同時とす る設定 $(\tau=0 \mu \mathrm{s})$ から, 電極間の LTV ガスの存在がほ ぼ無視できると考えられる $\tau=1000 \mu \mathrm{s}$ までを比較した . $(\tau=5 \mu \mathrm{s}$ については, 当初 $\tau=10 \mu \mathrm{s}$ の設定としたもの が, サイリスタへのゲート信号とイグナイタへの着火信号 とのずれにより短くなったものである .) また, PD と SD のコンデンサ容量比 $C_{\mathrm{A}} / C_{\mathrm{B}}$ は , $4 / 0,3 / 1,2 / 2,1 / 3$ の 4 ケースとした . 単段放電と二段放電ともに, 動作間隔は約 1 s である .

\section{4. 実 験 結 果}

4.1 二段放電動作の確認 単段放電動作時および二段 放電動作時 $(\tau=0,5,100,1000 \mu \mathrm{s})$ のPPT の放電電流波 形の比較を第 4 図に示す. 同図 $(\mathrm{a})$ （e) 全てにおいて総投
入エネルギ $E$ は約 $23 \mathrm{~J}$ であり，(b)〜 (e) の二段放電動作 については $C_{\mathrm{A}} / C_{\mathrm{B}}=2 / 2$ である .

同図 (a)より, 単段放電動作では, 通常の PPT のパル ス放電において観察される減衰振動波形が得られている. (放電時間が $60 \mu \mathrm{s}$ 程度と比較的長くかつ減衰が早いのは， 既述のように放電回路のインダクタンスおよび抵抗が他機 関において研究されている $\mathrm{PPT}^{1,7)}$ に比較して大きいため である .) これに対し，同図 (b)〜 (e) の二段放電動作では 放電電流の負成分はほぼ 0 であり，コンデンサとスラスタ 陽極との間に設置したサイリスタにより，電流の反転が妨 げられていることが確認できる . 同図 (b)では, 使用した 回路は二段放電用であるが，放電間隔 $\tau$ が 0 であるため，

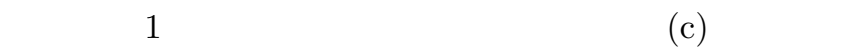
も，放電間隔 $\tau$ が放電の持続時間に比較して小さいため, 1 ピークの波形が得られている. $\tau=100 \mu \mathrm{s}$ と $\tau=1000 \mu \mathrm{s}$ の設定については, 放電間隔が十分大きいため, 独立した 2 つの放電ピークが観測された .

また, 上記 $(\mathrm{c})$ ～(e) の各場合における SD 開始時のイグ ナイタの動作については， $\tau=1000 \mu \mathrm{s}$ の設定では SD 用の イグニション放電によって SD 主放電が誘起されていたが， $\tau=5 \mu \mathrm{s}$ および $\tau=100 \mu \mathrm{s}$ の場合には SD 用イグニショ ンの前に (サイリスタにゲート信号が到達した時点で) SD 主放電が始まっており, この両者については SD 用イグニ ションは不要であることか確認された .この結果は , PD 開 始後少なくとも $100 \mu \mathrm{s}$ までは, 電極間に PD による LTV 
第 2 表 $\mathrm{PD}$ と SD のコンデンサ容量比によるインパルスビットの 比較 $(E \approx 43 \mathrm{~J}, \tau=5 \mu \mathrm{s})$

\begin{tabular}{lcccc}
\hline Capacitance ratio, $C_{\mathrm{A}} / C_{\mathrm{B}}$ & $4 / 0$ & $3 / 1$ & $2 / 2$ & $1 / 3$ \\
\hline Impulse bit, $I_{\mathrm{b}}(\mu \mathrm{N} \cdot \mathrm{s})$ & 69 & 93 & 104 & 87 \\
\hline
\end{tabular}

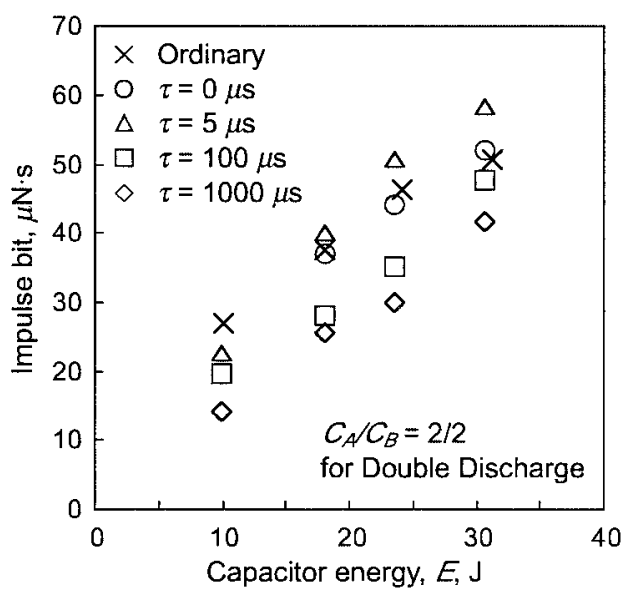

第 5 図＼cjkstart放電間隔によるインパルスビットの比較

ガスが存在することを示唆している .

次に, $\mathrm{PD}$ と $\mathrm{SD}$ のコンデンサ容量比 $C_{\mathrm{A}} / C_{\mathrm{B}}$ (投入エネ ルギ比と等価) を変化させた場合のインパルスビットの比 較を第 2 表に示す .ここでは PD と SD との放電間隔 $\tau$ は $5 \mu \mathrm{s}$ ，総投入エネルギ $E$ は約 $43 \mathrm{~J}$ とした . 同表より，二段 放電動作時のインパルスビットは, $C_{\mathrm{A}} / C_{\mathrm{B}}=2 / 2$ とした場 合に最も大きく,$C_{\mathrm{A}} / C_{\mathrm{B}}=4 / 0$ の場合に最も小さいこと か確認できる .これらのインパルスビットの違いは，A-ch または B-ch への電流の偏りにより, 第 1 図に示した電気 回路の抵抗成分による損失が変化することによって生じる ものと考えられるが, 弚の詳細な理解のためには今後さら に検討が必要である .

これらの結果により，今回設計·製作した二段放電用 $\mathrm{PPT}$ 回路が適正に作動したことが示された．以下では，インパ ルスビットが最大となった $C_{\mathrm{A}} / C_{\mathrm{B}}=2 / 2$ の場合について， 放電間隔 $\tau$ の影響に重点をおいて, PPT の二段放電動作 による推進性能変化について述べる。

4.2 放電間隔の影響 単段放電動作および二段放電動 作 $(\tau=0,5,100,1000 \mu \mathrm{s})$ におけるインパルスビットと投 入エネルギの関係を第 5 図に示す .ここでは，投入エネル ギ $E$ を約 10〜31 J $(\tau=0 \mu \mathrm{s}$ については約 18〜31 J) の 範囲で設定しており，第 4 図に示した放電電流波形は本図 中の $23 \mathrm{~J}$ 付近の各点に対応する .

第 5 図は, 二段放電のインパルスビットが, 弚の放電間 隔に強く依存することを示している.単段放電 (Ordinary) を基準とした場合， $\tau=100 \mu \mathrm{s}$ および $\tau=1000 \mu \mathrm{s}$ の場合 のインパルスビットは全エネルギ領域において単段放電より も小さいのに対し， $\tau=0 \mu \mathrm{s}$ ではほぼ同等であり， $\tau=5 \mu \mathrm{s}$ の場合には， $E \approx 10 \mathrm{~J}$ の点を除いて単段放電よりも大きな インパルスビットが得られている．以下に，推力簡易計算 モデル8)を用いて，この放電間隔の影響について考察する。
第 3 表 各放電間隔設定におけるインパルスビットの理論値と実験値 との比較 $\left(E \approx 23 \mathrm{~J}, C_{\mathrm{A}} / C_{\mathrm{B}}=2 / 2\right)$

\begin{tabular}{lcc}
\hline & $\begin{array}{c}\text { Calculation } \\
(\mu \mathrm{N} \cdot \mathrm{s})\end{array}$ & $\begin{array}{c}\text { Measurement } \\
(\mu \mathrm{N} \cdot \mathrm{s})\end{array}$ \\
\hline$\tau=0 \mu \mathrm{s}$ & 121 & 44 \\
$\tau=5 \mu \mathrm{s}$ & 118 & 51 \\
$\tau=100 \mu \mathrm{s}$ & 92 & 35 \\
$\tau=1000 \mu \mathrm{s}$ & 94 & 30 \\
(Ordinary) & $(108)$ & $(46)$ \\
\hline
\end{tabular}

平行平板電極型 $\mathrm{PPT}$ の電磁作用による推力 $T$ は, 放電 電流による自己誘起磁場の発生および両者の相互作用によ るローレンツ加速が損失なく行われると仮定した場合，次 式で表すことができる .

$$
T(t)=\frac{\mu_{0} J(t)^{2}}{2}\left(\frac{h}{d}\right)
$$

ここで, $\mu_{0}$ は真空の誘電率， $J(t)$ は各時間 $t$ における放電 電流, $h$ は電極間隔, $d$ は電極幅である.さらに, 1 回の推 力発生動作によるインパルスビットは, 放電持続時間を $t_{\mathrm{d}}$ として以下のように求まる.ここで, 二段放電動作の場合 の放電持続時間 $t_{\mathrm{d}}$ とは, $\mathrm{PD}$ 開始から $\mathrm{SD}$ 終了までの時間 である。

$$
I_{\mathrm{b}}=\int_{0}^{t_{\mathrm{d}}} T(t) \mathrm{d} t
$$

第 4 図 $(\mathrm{b})$ （e) の各設定における放電電流変化を上式に 代入し， $E \approx 23 \mathrm{~J}$ でのインパルスビットを計算した結果 を第 5 图中の測定結果とともに第 3 表に示す.(第 4 図 (a) の単段放電については, 使用回路が異なるため参考值とし て示した .) 測定結果に比較して計算結果が 2 倍以上の值と なっているのは, インパルスビットの算出において, 放電 電流による自己誘起磁場の発散成分およびローレンツ加速 の推力軸方向外成分を考慮していないためである．

第 3 表中の計算結果は, 放電チャネル内の放電・加速機構 が全ての設定において同一と仮定したものであるため，こ れを測定結果と比較することにより以下の考察が可能であ る.まず $\tau=0 \mu \mathrm{s}$ と $\tau=5 \mu \mathrm{s}$ とを比較すると, 放電電流 波形がほぼ同樣なために，両者のインパルスビットの計算 值は同等であるが，実験值では $\tau=5 \mu \mathrm{s}$ の方が約 $10 \%$ 大 きい.この違いは, $\tau=0 \mu \mathrm{s}$ の場合には PD と SD とが同 時に発生するのに対し， $\tau=5 \mu \mathrm{s}$ の場合には $\mathrm{SD}$ 開始時に すでに $5 \mu \mathrm{s}$ 分の中性粒子群および荷電粒子群が推進阂近傍 に存在しているために, 弚の残留推進剂ガスが SD におい て電離・加速されたことに因るものと推察できる .

また， $\tau=100 \mu \mathrm{s}$ と $\tau=1000 \mu \mathrm{s}$ の場合については，両 者のインパルスビットが計算結果においても他の設定に比 較して $25 \%$ 程度小さい .このことから, 実験においてこの 両者のインパルスビットが他の設定に比較して小さかった 主な原因は，PD と SD とが光れ午れ独立した放電となった ことで, エネルギ投入に要する時間が長くなった点にある と考えられる.一方， $\tau=100 \mu \mathrm{s}$ と $\tau=1000 \mu \mathrm{s}$ のインパ 
第 4 表 単段放電と二段放電との推進性能比較

\begin{tabular}{lccccc}
\hline & $E$ & $I_{\mathrm{b}}$ & $\Delta m$ & $I_{\mathrm{sp}}$ & $\eta_{\mathrm{t}}$ \\
& $(\mathrm{J})$ & $(\mu \mathrm{N} \cdot \mathrm{s})$ & $(\mu \mathrm{g})$ & $(\mathrm{s})$ & $(\%)$ \\
\hline Ordinary & 44 & 81 & 5.9 & 1400 & 1.3 \\
Double $(\tau=5 \mu \mathrm{s})$ & 43 & 104 & 6.2 & 1700 & 2.0 \\
\hline
\end{tabular}

ルスビットを互いに比較した場合，放電・加速機構の違い を考慮していない計算值ではほぼ同等であるのに対し，実 験結果では $\tau=100 \mu \mathrm{s}$ の場合の方が約 $12 \%$ 大きい . この 違いは, $\tau=100 \mu \mathrm{s}$ の場合には, PD で生じた LTV ガス が SD 開始時に放電チャネル内に残留しており，光の一部 が SD によって電磁加速されたことにより生じたものと考 えられる .

これらの点から，二段放電動作を行うことによって推進 剂ガスの電磁加速割合を増加させることが可能であると言 うことができる.ただし本実験の設定では, 通常のPPTよ りも大きなインパルスビットが得られたのは, PD と SD が 1 つの放電波形となる短時間の放電間隔の場合のみであつ た . 以下に，優位性が見られた $\tau=5 \mu \mathrm{s}$ の場合について， 単段放電との推進性能の比較を述べる.

4.3 単段放電と二段放電との推進性能比較 単段放電 と二段放電 $\left(\tau=5 \mu \mathrm{s}, C_{\mathrm{A}} / C_{\mathrm{B}}=2 / 2\right)$ の両者について, 投入エネルギが約 $43 \mathrm{~J}$ の点においてマスショットおよびイ ンパルスビットの測定を行い, 推進性能を求めた . 両者の 比較を第 4 表に示す. 同表より, 二段放電 $(\tau=5 \mu \mathrm{s})$ の 場合には, 単段放電と比較して $25 \%$ 以上大きいインパルス ビットが得られていることが分かる．この違いは，投入エ ネルギが大きいほど両者のインパルスビットの差が広がる とする第 5 図の傾向と一致するものである . このインパル スビットの違いに対し，両者のマスショットの差は約 $5 \%$ で あることから，二段放電を用いたことにより，推進剂消費 の増加を伴わずにインパルスビットが増大したことが確認 できる.この結果は, 二段放電の適用により $\mathrm{PPT}$ の推進 性能全般の向上が可能であることを示すものである．

また，比推力が推進剂ガスの有効排気速度に比例すること を考慮すると，第 4 表に示される二段放電動作 $(\tau=5 \mu \mathrm{s})$ による比推力の増加は, 有効排気速度の増大を表すと言え る.この結果は，第 3 表より得られた推察を支持するもの であり，二段放電動作の適用により，全推進剂蒸気化量の うち電磁加速される推進剂ガスの割合が増加したものと考 えられる .

4.4 今後の課題 上述の結果により, $\mathrm{PPT}$ への二段放 電動作の適用は，蒸気化した推進剂を有効に電離・加速する ために有効であることが示された . しかしながら現段階で は, 放電チャネル内および電気回路部での現象には不明確 な点があり, 定量的な説明がされていない問題が多い．こ
れらの問題を検討するためには, 放電部の荷電粒子や中性 粒子の物性を高速度カメラやプローブ診断等により測定し， 投入したエネルギの各物理過程への配分状態を評価するこ とが必要である．また，電気回路部の抵抗およびインダク タンスを小さくすることで単位時間あたりの放電部へのエ ネルギ投入量を増加させ , 推進性能の向上を图ることも今 後の課題である

$$
\text { 5. ま と め }
$$

パルス型プラズマスラスタの性能低下要因の 1 つと考え られている Late-Time Vaporization を軽減する手段とし て二段放電動作を提案し，关の初期実験を行った。二段放 電動作用の電気回路は, 2 系統のコンデンサおよび大容量サ イリスタにより構成され，放電電流波形の測定により同回 路が適正に動作することか確認された .さらに，放電間隔 をパラメータとした実験を行った結果，二段放電動作の適 用により，電磁加速される推進剂ガスの割合が増加するこ とが示され，これには Late-Time Vaporization ガスの利 用も含まれることが示唆された．また，二段放電の放電間 隔を放電時間に比較して短く設定した場合には, 単段放電 の場合よりも，インパルスビット，比推力および推進効率 が上昇することが確認され，適正なパラメータの選択によ り，推進性能全般の向上が可能であることが示された . 今 後は, 放電回路の改良により更なる推進性能の向上を図る とともに, 放電チャネル内の詳細な現象評価を進めていく 予定である .

\section{参 考 文 献}

1) Burton, R. and Turchi, P.: Pulsed Plasma Thruster, J. Propul. Power, 14 (1998), pp. 716-735.

2) Spanjers, G., McFall, K., Gulczinski III, F. and Spores, R.: Investigation of Propellant Inefficiencies in a Pulsed Plasma Thruster, AIAA Paper 96-2723, 1996.

3) Spanjers, G., Malak, J., Leiweke, R. and Spores, R.: Effect of Propellant Temperature on Efficiency in the Pulsed Plasma Thruster, J. Propul. Power, 14 (1998), pp. 545-553.

4) Mikellides, P. and Turchi, P.: Modeling of Late-Time Ablation in Teflon Pulsed Plasma Thrusters, AIAA Paper 96$2733,1996$.

5) Okada, M., Okawa, Y. and Tachibana, T.: Double Discharge Operation for Pulsed Plasma Thrusters, 27th International Electric Propulsion Conference, IEPC Paper 01-156, 2001.

6) Yanagi, R. and Kimura, I.: A New Type Target for the Measurement of Impulse Bits of Pulsed Plasma Thrusters, AIAA Paper 81-0712, 1981.

7) Igarashi, M., Kumagai, N., Sato, K., Tamura, K., Takegahara, H., Okamoto, H., Wakizono, T. and Hashimoto, H. Performance Improvement of Pulsed Plasma Thruster for Micro Satellite, 27th International Electric Propulsion Conference, IEPC Paper 01-152, 2001.

8) Jahn, R.: Physics of Electric Propulsion, McGraw-Hill, New York, 1968, pp. 269-272. 